\title{
THE ASSOCIATION BETWEEN PERSONAL HYGIENE AND THE OCCURRENCE OF CONTACT DERMATITIS AMONG FARMERS AT PUSKESMAS LAMEURU, RANOMEETO BARAT, SOUTH EAST SULAWESI
}

\author{
Suharjuniatin Habibi, Wa Ode Fera Falawati, Harmilan
}

Masters Program in Public Health, School of Health Sciences Mandala Waluya, Kendari

\begin{abstract}
Background: Contact dermatitis is an eczematous eruption caused by external agents, which can be broadly divided into irritant substances that have a direct toxic effect on the skin (irritant contact dermatitis, ICD) and allergic chemicals where immune delayed hypersensitivity reactions occur (allergic contact dermatitis, ACD). This study aimed to determine the association between personal hygiene and the occurrence of contact dermatitis among farmers at community health center Lameuru, Ranomeeto Barat district, South East Sulawesi.

Subjects and Method: This was a cross sectional study conducted at Lameuru Community health center, Ranomeeto Barat district, South East Sulawesi. A total sample of 100 farmers was selected for this study by simple random sampling. The dependent variable was the occurrence of contact dermatitis. The independent variables were personal hygiene, clothes hygiene, and cleanliness of the bed. The data was collected by questionaire and analyzed by chi square and odds ratio as the measure of association.

Results: Poor personal hygiene $(\mathrm{OR}=5.13 ; 95 \% \mathrm{CI}=2.16$ to $12.19 ; \mathrm{p}<0.001)$, poor clothes hygiene $(\mathrm{OR}=8.46 ; 95 \% \mathrm{CI}=3.39$ to 21.08 ; $\mathrm{p}<0.001)$, and poor cleanliness of the bed $(\mathrm{OR}=$ $7.37 ; 95 \% \mathrm{CI}=3.03$ to $17.89 ; \mathrm{p}<0.001$ ) were associated with the occurrence of contact dermatitis.

Conclusion: Personal hygiene, clothes hygiene, and cleanliness of the bed are associated with the occurrence of contact dermatitis.
\end{abstract}

Keywords: personal hygiene, clothes hygiene, cleanliness of the bed, dermatitis

Correspondence:

Suharjuniatin Habibi. Masters Program in Public Health, School of Health Sciences Mandala Waluya, Jl. A.H.Nasution No. G 37, Kendari, South East Sulawesi.

Email: Suharjuniatin123@gmail.com. Mobile: 085298348022

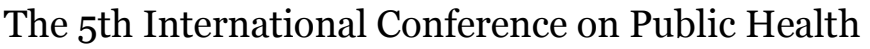

Best Western Premier Hotel, Solo, Indonesia, February 13-14, 2019 | 177 https://doi.org/10.26911/theicph.2019.02.22 